\title{
Efektifitas Asuhan Keperawatan Gawat Darurat Terintegrasi Berbasis Aplikasi Web Sistem Pakar Terhadap Ketepatan dan Kelengkapan Dokumentasi
}

\section{Sistem Pakar Terhadap Ketepatan dan Kelengkapan Dokumentasi}

\author{
Suryagustina ${ }^{1}$, Lensi Natalia Tambunan ${ }^{2}$, Retu Vogan Awan ${ }^{3}$ \\ ${ }^{1}$ Program Studi Sarjana Keperawatan STIKes Eka Harap Palangka Raya \\ ${ }^{2}$ Program Studi Sarjana Kesehatan Masyarakat STIKes Eka Harap Palangka Raya \\ ${ }^{3}$ Universitas Palangka Raya \\ *correspondence author: Telepon: 085389198957, Fax: 0536-3227707, \\ Email: gustin.yaya@gmail.com
}

DOI: https://doi.org/10.33859/dksm.v10i2.482

\begin{abstract}
Abstrak
Latar Belakang: Dokumentasi keperawatan yang berlaku di UGD (Unit Gawat Darurat) saat ini umumnya dilakukan secara tertulis (paper based documentation). Metode ini mempunyai kelemahan yaitu memerlukan waktu yang cukup lama untuk mengisi form yang tersedia, membutuhkan biaya pencetakan form yang cukup mahal, sering hilang atau terselip, memerlukan tempat penyimpanan yang luas dan menyulitkan pencarian kembali saat diperlukan. Disamping itu masih banyak perawat yang belum menyadari bahwa tindakan yang dilakukan harus dipertanggungjawabkan, untuk itu perlu adanya inovasi pencatatan dengan menggunakan pencatatan berbasis aplikasi web.

Tujuan: Penelitian ini bertujuan untuk mengetahui pengaruh penggunaan asuhan keperawatan gawat darurat terintegrasi berbasis aplikasi web Sistem Pakar terhadap ketepatan dan kelengkapan dokumentasi keperawatan di ruang IGD RSUD dr. Doris Sylvanus Palangka Raya.

Metode: Desain penelitian yang digunakan Pre eksperiment dengan pendekatan The One Group Pratest-Posttes Design. Pengambilan sample dengan menggunakan purposive sampling. Populasi pada penelitian ini adalah mahasiswa keperawatan yang menjalani praktek di IGD. Sampel berjumlah 24 responden di RSUD. dr. Doris Sylvanus Palangka Raya

Hasil: Berdasarkan uji statistik menunjukan nilai significanci pvalue <nilai $\alpha$ dengan tingkat significanci $\alpha=0,05$. Nilai significanci menggunakan Uji Wilcoxon di peroleh Sig. (2-tailed) sebesar 0.001 dan 0.002 yang artinya $\mathrm{H} 0$ ditolak sehingga terdapat pengaruh penggunaan asuhan keperawatan gawat darurat terintegrasi berbasis aplikasi web Sistem Pakar terhadap ketepatan dan kelengkapan dokumentasi keperawatan di ruang IGD RSUD dr. Doris Sylvanus Palangka Raya.

Kesimpulan: Hasil penelitian menunjukkan bahwa penggunaan asuhan keperawatan gawat darurat terintegrasi berbasis aplikasi web Sistem Pakar efektif dalam meningkatkan ketepatan dan kelengkapan dokumentasi keperawatan. Hasil penelitian ini dapat memberi manfaat bagi pelayanan kesehatan, sehingga mempermudah perawat dalam melakukan dokumentasi sebagai legalitas tindakan dan perlindungan hukum.
\end{abstract}

Kata Kunci: Aplikasi Web, Dokumentasi Asuhan Keperawatan, Ketepatan, Kelengkapan, Gawat Darurat. 
Dinamika Kesehatan Jurnal Kebidanan dan Keperawatan Vol 10 No. 2 Desember 2019 ( ISSN: 2086-3454 EISSN: 2549-4058)

url: http://ojs.dinamikakesehatan.unism.ac.id DOI: https://doi.org/10.33859/dksm.v10i2

Efektifitas Asuhan Keperawatan Gawat Darurat Terintegrasi Berbasis Aplikasi Web Sistem Pakar Terhadap Ketepatan dan Kelengkapan Dokumentasi

\title{
The Effectiveness of Integrated Emergency Nursing Care Based on Web Application Expert System Against the Accuracy and Completeness of Documentation
}

\begin{abstract}
Background: Nursing documentation that applies in the ER (Emergency Unit) is currently generally carried out in writing (paper based documentation). This method has the disadvantage of requiring a long time to fill out the available forms, requiring the cost of form printing which is quite expensive, often lost or tucked away, requires a large storage area and makes it difficult to search again when needed. Besides that there are still many nurses who have not realized that the actions taken must be accounted for, for that there is a need for innovation in recording using web application-based recording.

Objective: This study aims to determine the effect of the use of integrated emergency nursing care based on Expert System web applications on the accuracy and completeness of nursing documentation in the emergency room of the RSUD dr. Doris Sylvanus Palangka Raya.

Method: The study design used Pre experiment with the approach of The One Group PratestPosttes Design. Sampling using purposive sampling. The population in this study were nursing students who underwent practice at the ED. The sample amounted to 24 respondents in the RSUD. dr. Doris Sylvanus Palangka Raya.

Results: Based on the statistical test shows thevalue of significance $p$ value $<$ value $\alpha$ with alevel of significance $=0$ 0.05.value Significant using a statistical Wilcoxon test obtained by Sig. (2-tailed) of 0.001 and 0.002 which means that $H O$ is rejected so that there is an influence of the use of integrated emergency nursing care based on the Expert System web application on the accuracy and completeness of nursing documentation in the emergency room of the RSUD Dr. Doris Sylvanus Palangka Raya.

Conclusion: The results of the study show that the use of integrated nursing care based on web applications Expert Systems is effective in increasing the accuracy and completeness of nursing documentation. The results of this study can benefit health services, making it easier for nurses to carry out documentation as the legality of legal action and protection.
\end{abstract}

Keywords: Web Application, Nursing Care Documentation, Accuracy, Completeness, Emergency.

\section{PENDAHULUAN}

Kondisi gawat darurat merupakan keadaan

klinis dimana klien membutuhkan tindakan

medis segera guna penyelamatan nyawa

serta pencegahan tujuannya yaitu

tercapainya pelayanan kesehatan yang optimal bagi pasien secara cepat dan tepat

serta terpadu dengan waktu respon selama

lima menit dan waktu definitif tidak lebih

dari dua jam (Basoki dkk, 2008 dalam

Nonutu, dkk, 2015). Diperlukan asuhan

keperawatan yang tepat untuk menentukan 
dasar penanganan pasien dalam kondisi sehari-hari serta kejadian luar biasa dengan tujuan utama keselamatan pasien, keputusan yang tepat memerlukan data yang tepat dan lengkap, meminimalkan trauma, kecacatan, dan atau meninggal dunia.

Dokumentasi keperawatan yang berlaku di rumah sakit saat ini umumnya dilakukan secara tertulis (paper based documentation). Metode ini mempunyai kelemahan yaitu memerlukan waktu yang cukup lama untuk mengisi form yang tersedia, membutuhkan biaya pencetakan form yang cukup mahal, sering hilang atau terselip, memerlukan tempat penyimpanan yang luas dan menyulitkan pencarian kembali saat diperlukan. Disamping itu masih banyak perawat yang belum menyadari bahwa tindakan yang dilakukan harus dipertanggungjawabkan. Perawat juga banyak yang tidak tahu data apa yang harus dimasukkan dan bagaimana dokumentasi keperawatan yang benar, untuk itu perlu adanya inovasi pencatatan dengan menggunakan pencatatan berbasis aplikasi web.

Menurut Pertiwi \& Sugiyanto (2014), menyatakan dokumentasi yang lengkap dan benar akan memudahkan informasi bagi pihak rumah sakit. Dokumentasi yang lengkap dapat digunakan bagi referensi pelayanan kesehatan, perlindungan hukum, menunjang informasi, penjamin mutu, menetapkan diagnosa, prosedur pengkodean, pengertian biaya, penelitian, pendidikan, serta sebagai penunjang akreditasi rumah sakit.

Berdasarkan hasil penelitian Berthiana (2012) tentang penerapan standar asuhan keperawatan pada pasien pada bulan September 2012 menyatakan bahwa ratarata $61,9 \%$ dengan kategori nilai cukup; khususnya untuk dokumentasi tahap pengkajian sebesar $55 \%$ telah sesuai standar asuhan keperawatan. Salah satu alasan tidak melakukan pengisian dokumentasi adalah kurang mengerti terhadap standar asuhan keperawatan dikarenakan tidak ada panduan dalam 
melakukan dokumentasi asuhan

keperawatan.

Hasil penelitian Suryagustina, (2017) Di

IGD RSUD Mas Amsyar Kasongan dan

RSUD Pulang Pisau menyatakan bahwa

ada perbedaan efektifitas ketepatan dan

kelengkapan dokumentasi antara kelompok

kontrol dan kelompok intervensi yang diberikan sosialisasi penggunaan format dan panduan keperawatan terintegrasi.

Penelitian ini juga masih menggunakan sistem manual sehingga peneliti tertarik melanjutkan penelitian dengan mengembangkan asuhan keperawatan gawat darurat terintegrasi berbasis aplikasi web Sistem Pakar untuk mengetahui pengaruhnya terhadap ketepatan dan kelengkapan dokumentasi keperawatan di ruang IGD RSUD Doris Sylvanus Palangka Raya.

\section{METODE}

Desain penelitian mengunakan pre eksperimen, menjelaskan hubungan sebab akibat dengan melibatkan satu kelompok subjek tanpa kelompok kontrol, dimana dalam rancangan ini kelompok eksperimen diberi perlakuan (Nursalam, 2011). Desain penelitian menggunakan pretest-posttest pada kelompok tunggal (The One Group Pratest-Posttest) dengan pola berikut.
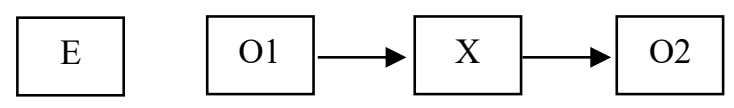
Gambar 1. Desain Penelitian

Sampel dalam penelitian ini menggunakan purposive sampling yaitu 24 orang mahasiswa keperawatan yang menjadi kelompok intervensi (diberi aplikasi asuhan keperawatan berbasis web sistem pakar) di IGD RSUD dr. Doris Sylvanus Palangka Raya. Waktu penelitian adalah jangka waktu yang dibutuhkan penulis untuk memperoleh data penelitian yang dilaksanakan, yaitu pada bulan Juli-September 2019.

Instrumen penelitian ini mengacu pada instrumen A dari Depkes (2005) yang meliputi observasi untuk ketepatan dokumentasi berjumlah 22 soal dan untuk observasi kelengkapan dokumentasi berjumlah 29 soal. 
Analisis data dilakukan analisis univeriat dan bivariate. Analisis univariat dilakukan pada karakteristik responden yang terdiri dari jenis kelamin, Pendidikan dan umur serta ketepatan dan kelengkapan dokumentasi sebelum dan sesudah diterapkan aplikasi asuhan keperawatan berbasis web sistem pakar. Analisis bivariat dilakukan untuk melihat perbedaan masing-masing variabel dependen dan independen, perbedaan dianggap bermakna bila nilai $p$ adalah $<$ level of significance $(<5 \%$ $=0,05)$. Analisis menggunakan uji beda berpasangan (Uji Wilcoxon). Prinsip etika penelitian tetap dilakukan untuk melindungi subjek penelitian.

\section{HASIL}

\section{Analisis Univariat}

\section{Karakteristik Responden Penelitian}

Deskripsi identitas responden diperlukan untuk mengetahui karakteristik dari responden yang telah berpartisipasi dalam penelitian efektifitas asuhan keperawatan gawat darurat terintegrasi berbasis aplikasi web sistem pakar terhadap ketepatan dan kelengkapan dokumentasi. Karakteristik responden tersebut meliputi jenis kelamin, umur dan pendidikan yang ditempuh.

Tabel 1 Karakteristik Responden berdasarkan Jenis Kelamin, Pendidikan dan Umur di IGD RSUD dr. Doris Sylvanus Palangka Raya

\begin{tabular}{|c|c|c|}
\hline \multirow{2}{*}{ Karakteristik } & \multicolumn{2}{|c|}{ Jumlah } \\
\hline & $\mathrm{N}$ & $\%$ \\
\hline \multicolumn{3}{|l|}{ Jenis Kelamin } \\
\hline Perempuan & 15 & 62.5 \\
\hline Laki-laki & 9 & 37.5 \\
\hline \multicolumn{3}{|l|}{ Pendidikan } \\
\hline Profesi Ners & 19 & 79.16 \\
\hline DIII Kep. & 5 & 20.83 \\
\hline \multicolumn{3}{|l|}{ Umur } \\
\hline $19-20$ & 7 & 29.16 \\
\hline $21-22$ & 17 & 70.83 \\
\hline
\end{tabular}

Tabel 1. tersebut di atas semua responden adalah mahasiswa keperawatan yang praktek di ruang IGD RSUD dr. Doris Sylvanus Palangka Raya. Berdasarkan jenis kelamin didapatkan mayoritas responden adalah perempuan sebanyak $62.5 \%$. Karakteristik responden berdasarkan pendidikan yang ditempuh saat ini terbanyak adalah pendidikan profesi Ners yaitu $79.16 \%$ dan dominan responden berumur $21-22$ tahun yaitu $70.83 \%$.

2. Karakteristik Ketepatan dan Kelengkapan Dokumentasi 
Berikut merupakan karakteristik ketepatan dan

kelengkapan dokumentasi keperawatan.

Tabel 2. Deskripsi Ketepatan Dokumentasi Keperawatan Sebelum dan Setelah Diterapkan asuhan keperawatan gawat darurat terintegrasi berbasis aplikasi web sistem pakar di IGD RSUD dr. Doris Sylvanus Palangka Raya Tahun 2019

\begin{tabular}{lccccccc}
\hline & Baik & $\%$ & Cukup & $\%$ & Kurang & $\%$ & N \\
\hline $\begin{array}{l}\text { Ketepatan } \\
\text { sebelum }\end{array}$ & 5 & 20.83 & 12 & 50 & 7 & 29.16 & 24 \\
$\begin{array}{l}\text { Ketepatan } \\
\text { setelah }\end{array}$ & 19 & 79.16 & 5 & 20.83 & - & - & 24 \\
\hline
\end{tabular}

Tabel 2 menunjukkan hasil observasi

ketepatan dokumentasi sebelum dan setelah

diterapkan asuhan keperawatan gawat darurat

terintegrasi berbasis aplikasi web sistem pakar

menunjukkan peningkatan jumlah

responden yang pada data sebelum

penerapan aplikasi web sitem pakar hanya

$20.83 \%$ menjadi $79.16 \%$ dan tidak ada

responden dengan ketepatan dokumentasi

kategori kurang pada hasil setelah

penerapan aplikasi.
Tabel 3 Deskripsi Kelengkapan Dokumentasi Keperawatan Sebelum dan Setelah Diterapkan asuhan keperawatan gawat darurat terintegrasi berbasis aplikasi web sistem pakar di IGD RSUD dr. Doris Sylvanus Palangka Raya Tahun 2019

\begin{tabular}{lccccccc}
\hline & Baik & $\%$ & Cukup & $\%$ & Kurang & $\%$ & $\mathrm{~N}$ \\
\hline $\begin{array}{l}\text { Kelengkapan } \\
\text { sebelum }\end{array}$ & 7 & 29.16 & 15 & 62.5 & 2 & 8.33 & 24 \\
\hline $\begin{array}{l}\text { Kelengkapan } \\
\text { setelah }\end{array}$ & 17 & 70.83 & 7 & 29.16 & - & - & 24 \\
\hline
\end{tabular}

Tabel 3 menunjukkan hasil observasi kelengkapan dokumentasi sebelum dan setelah diterapkan asuhan keperawatan gawat darurat terintegrasi berbasis aplikasi web sistem pakar menunjukkan peningkatan jumlah responden yang pada data sebelum penerapan aplikasi web sitem pakar hanya $29.16 \%$ menjadi $70.83 \%$ dan tidak ada responden dengan kelengkapan dokumentasi kategori kurang pada hasil setelah penerapan aplikasi.

\section{Analisis Bivariat}

Analisis bivariat dilakukan pada variabel ketepatan dan kelengkapan sebelum dan setelah di terapkan aplikasi web sistem pakar pada asuhan keperawatan gawat darurat dan menyakinkan penelitian ini bahwa perubahan yang terjadi disebabkan karena intervensi yang diberikan peneliti. 
Hasil analisis pada dua variabel ketepatan dan kelengkapan dokumentasi keperawatan gawat darurat terintegrasi. Observasi dilakukan sebanyak dua kali, yaitu sebelum dilakukan intervensi dan setelah dilakukan intervensi.

\section{Ketepatan Dokumentasi}

Berikut merupakan hasil uji statistik ketepatan dokumentasi sebelum dan setelah di terapkan asuhan keperawatan gawat darurat terintegrasi berbasis aplikasi web sistem pakar di IGD RSUD dr. Doris Sylvanus Palangka Raya.

Tabel 4 Hasil Analisis Ketepatan Dokumentasi Keperawatan Setelah Diterapkan asuhan keperawatan gawat darurat terintegrasi berbasis aplikasi web sistem pakar di IGD RSUD dr. Doris Sylvanus Palangka Raya Tahun 2019

\begin{tabular}{lcccccccc}
\hline & N & Mean & Median & SD & Min & Max & Z & $\begin{array}{c}\text { P } \\
\text { value }\end{array}$ \\
\hline $\begin{array}{l}\text { Ketepatan } \\
\text { sebelum }\end{array}$ & 24 & 14.77 & 19.12 & 3.68 & 9.09 & 18.18 & & \\
$\begin{array}{l}\text { Ketepatan } \\
\text { setelah }\end{array}$ & 24 & 87.23 & 85.49 & 11.14 & 68.67 & 98.00 & & \\
\hline
\end{tabular}

Tabel 4 menunjukkan hasil observasi

ketepatan dokumentasi pada kelompok intervensi sebelum dan setelah diterapkan asuhan keperawatan gawat darurat terintegrasi berbasis aplikasi web sistem pakar menunjukkan selisih mean sebesar 59.58 dengan selisih standar deviasi 7.46. Hasil uji Wilcoxon menunjukkan p value $0.001<$ $\alpha 0.05$ maka terdapat pengaruh yang sangat signifikan pada ketepatan dokumentasi sebelum dengan setelah penerapan aplikasi.

2. Kelengkapan Dokumentasi

Berikut merupakan hasil uji statistik kelengkapan dokumentasi sebelum dan setelah di terapkan asuhan keperawatan gawat darurat terintegrasi berbasis aplikasi web sistem pakar di IGD RSUD dr. Doris Sylvanus Palangka Raya.

Tabel 5 Hasil Analisis Kelengkapan Dokumentasi setelah Diterapkan asuhan keperawatan gawat darurat terintegrasi berbasis aplikasi web sistem pakar di IGD RSUD dr. Doris Sylvanus Palangka Raya Tahun 2019

\begin{tabular}{|c|c|c|c|c|c|c|c|}
\hline & $\mathrm{N}$ Mean & Median & SD & Min & $\mathrm{Max}$ & Z & $\begin{array}{c}\mathrm{P} \\
\text { value }\end{array}$ \\
\hline $\begin{array}{l}\text { Kelengkapan } \\
\text { sebelum }\end{array}$ & 2421.46 & 21.23 & 3.11 & & 40.02 & \multirow{2}{*}{-4.281} & \multirow[b]{2}{*}{0.002} \\
\hline $\begin{array}{l}\text { Kelengkapan } \\
\text { setelah }\end{array}$ & $24 \quad 78.70$ & 80.10 & 15.15 & 56.74 & 97.00 & & \\
\hline
\end{tabular}

Berdasarkan tabel 5 menunjukkan hasil observasi kelengkapan dokumentasi setelah diterapkan asuhan keperawatan gawat darurat terintegrasi berbasis aplikasi web sistem pakar menunjukkan selisih mean sebesar 57.24 dengan selisih standar deviasi 12.04 Hasil uji Wilcoxon menunjukkan $\mathrm{p}$ value $0.002<\alpha 0.05$ maka terdapat pengaruh yang sangat signifikan 
pada kelengkapan dokumentasi sebelum dan setelah penerapan aplikasi.

\section{PEMBAHASAN}

\section{Karakteristik}

Berdasarkan jenis kelamin didapatkan mayoritas responden adalah perempuan sebanyak $62.5 \%$. Karakteristik responden berdasarkan pendidikan yang ditempuh saat ini terbanyak adalah pendidikan profesi Ners yaitu $79.16 \%$ dan dominan responden berumur 21-22 tahun yaitu $70.83 \%$.

Menurut Yanti \& Warsito (2013) menyatakan bahwa dari hasil penelitian yang dilakukan tidak ada hubungan tingkat pendidikan dengan kualitas dokumentasi keperawatan dengan $\mathrm{p}$ value $0.902>\alpha 0.05$. Hal ini didukung oleh Cheevakasemsook, et al. (2006) yang menyatakan bahwa perawat mungkin memiliki tingkat pengetahuan yang tinggi, namun terkadang perawat membuat hal tersebut sebagai sumber stress dan membuat mereka merasa tidak terampil, kurang motivasi, dan tidak percaya diri untuk melakukan tindakan dokumentasi asuhan keperawatan. Kurang terampilnya perawat dapat disebabkan karena kurangnya pengetahuan perawat tentang proses asuhan keperawatan merupakan inti dasar untuk melakukan dokumentasi keperawatan. Sedangkan untuk kurang motivasi dan tidak percaya diri perawat dikarenakan tidak dilakukan supervisi terus-menerus dan tidak ada sistem monitor oleh kepala ruangan (manajer).

Penelitian Yanti \& Warsito (2013) enyatakan bahwa tidak ada hubungan antara umur dengan kualitas dokumentasi proses asuhan keperawatan. Sehingga umur tidak mempengaruhi dokumentasi keperawatan secara langsung. Perawat yang berumur lebih muda berkaitan dengan faktor kepuasan terhadap pekerjaan belum dirasakan secara bermakna. Sedangkan perawat yang memiliki umur yang lebih dewasa, jika dilihat dari aspek kesehatan berkaitan dengan membutuhkan lebih lama waktu pemulihan cedera maka kemungkinan tingkat ketidakhadiran lebih tinggi dibandingkan karyawan muda. 
Untuk meningkatkan kemampuan melakukan dokumentasi maka perlu dilakukan pengembangan, seperti mengikuti seminar dan pelatihan secara berkesinambungan.

Namun, hal ini bertentangan dengan penelitian Wahyudi (2010) menyatakan bahwa umur perawat yang lebih muda cenderung kurang memiliki rasa tanggung jawab, kurang disiplin, sering berpindah pekerjaan, dan belum mampu berfikir rasional. Sehingga perawat yang memiliki umur lebih muda belum mampu melakukan dokumentasi asuhan keperawatan dengan tepat dan lengkap. Sejalan dengan hasil penelitian yang dilakukan oleh Diyanto (2007) bahwa umur mempengaruhi dokumentasi keperawatan, diperlukan motivasi yang dilakukan oleh kepala ruangan untuk memberikan dorongan kepada perawat yang memiliki umur lebih dewasa untuk melakukan dokumentasi. Umur berhubungan erat dengan pengalaman kerja perawat yang secara langsung dapat mempengaruhi kemampuan perawat dalam melakukan dokumentasi.

Bertambahnya umur seseorang menjadi semakin dewasa memberikan dampak secara tidak langsung pada kemampuan seorang perawat dalam melakukan dokumentasi keperawatan. Ilmu keperawatan selalu berkembang setiap waktu berdasarkan kebutuhan klien, demikian juga halnya dengan asuhan keperawatan gawat darurat terintegrasi berbasis web sistem pakar. Perawat umur lebih muda masih memerlukan bimbingan dan arahan dalam bersikap disiplin serta perlu ditanamkan rasa tanggung jawab sehingga pemanfaatan usia produktif lebih maksimal. Seiiring dengan bertambahnya umur maka diharapkan pengalaman kerja perawat juga bertambah dalam melakukan asuhan keperawatan gawat darurat berbasis aplikasi web sistem pakar.

Marton (2013) mengatakan bahwa menjadi perawat gawat darurat membutuhkan pengalaman dan pelatihan tentang kemampuan diri, keterampilan penilaian 
(pengkajian) yang baik, dasar pengetahuan yang kuat, berpikir kritis dan pengambilan keputusan, serta kemampuan berkomunikasi. Kemampuan diri perawat gawat darurat butuh pengalaman untuk mampu mengenal diri sehingga mampu memprioritaskan dengan cepat terkait kondisi klien. Keterampilan penilaian yang baik didapatkan dengan latihan secara terus menerus dan membutuhkan dasar pengetahuan yang baik. Kemampuan berpikir kritis dapat dilatih bertahap karena klien yang datang ke ruang gawat darurat merupakan klien yang tidak diketahui kondisi atau tidak terdiagnosis dengan baik. Perawat harus mempunyai kemampuan berpikir kritis untuk dapat membantu klien menangani masalah keluhan klien berdasarkan tanda dan gejala yang muncul. Penting melakukan pelatihan tentang dokumentasi asuhan keperawatan sehingga meningkatkan kemampuan perawat melakukan dokumentasi keperawatan dengan tepat dan lengkap. Hal ini didukung oleh penelitian Siswanto dkk. (2013) menyatakan bahwa pelatihan memiliki hubungan dengan kelengkapan pendokumentasian. Kemudian didukung oleh Okaisu (2014) mengungkapkan bahwa pelatihan perawat saja tidak cukup untuk meningkatkan kualitas dokumentasi keperawatan, perlu diberikan orientasi berulang, pendidikan secara terus menerus, perbaikan format dokumentasi, peningkatan keterampilan perawat, dan mendapatkan dukungan berkesinambungan dari pimpinan.

2. Ketepatan dan Kelengkapan

Dokumentasi Keperawatan

Ketepatan dokumentasi pada kelompok intervensi sebelum dan setelah diterapkan asuhan keperawatan gawat darurat terintegrasi berbasis aplikasi web sistem pakar menunjukkan selisih mean sebesar 59.58 dengan selisih standar deviasi 7.46. Hasil uji Wilcoxon menunjukkan p value $0.001<$ $\alpha 0.05$ maka terdapat pengaruh yang sangat signifikan pada ketepatan dokumentasi sebelum dengan setelah penerapan aplikasi. 
Hasil penelitian yang dilakukan oleh Herdiana (2013) menunjukkan bahwa fungsi pengarahan sebagian besar berada pada kategori tinggi yaitu sebanyak 57.1\%.

Fungsi pengarahan memiliki pengaruh terhadap dokumentasi asuhan keperawatan dengan nilai $\mathrm{p}$ value 0.027 . Penelitian ini sejalan dengan penelitian yang dilakukan oleh Dewi (2011), yang menemukan bahwa adanya hubungan yang bermakna antara fungsi pengarahan dengan penerapan keselamatan klien ( $\mathrm{p}$ value 0.001). Demikian pula dengan hasil penelitian yang dilakukan oleh Parmin (2009), yang menemukan bahwa ada hubungan yang signifikan antara fungsi manajemen pengarahan kepala ruang dengan motivasi perawat pelaksana ( $\mathrm{p}$ value 0.022 ).

Ketepatan dokumentasi keperawatan sangat erat kaitannya dengan asuhan keperawatan yang diberikan kepada klien. Asuhan keperawatan yang diberikan tepat pada klien menghasilkan ketepatan terhadap dokumentasi keperawatan. Asuhan keperawatan yang diberikan perawat pada klien harus memiliki standar praktik yang terdiri dari lima tahapan proses keperawatan, yaitu pengkajian, diagnosis, perencanaan, implementasi, dan evaluasi (National Council of State Boards of Nursing, 1982 dan Kemenkes, 2011). Selain itu, Nielsen, et al. (2014) menyatakan bahwa untuk meningkatkan kepatuhan terhadap standar praktik yang baik maka diperlukan dokumentasi berkualitas tinggi selain itu dapat meningkatkan keselamatan klien, meningkatkan kualitas dokumentasi dan meningkatkan ketepatan waktu dokumentasi. Proses keperawatan yang valid dan dapat diandalkan akan meningkatkan proses keperawatan klinis, beban pengumpulan data berkurang dan mengurangi error. Perawat professional harus memiliki standar praktik dalam melakukan asuhan keperawatan. Penggunaan format dan panduaan asuhan keperawatan yang tepat dan akurat dapat meningkatkan kemampuan perawat dalam melakukan dokumentasi keperawatan yang 
lebih baik dan meningkatkan ketepatan melakukan dokumentasi keperawatan. Ketepatan dokumentasi keperawatan mempengaruhi kualitas asuhan keperawatan yang diberikan, meningkatkan kepatuhan terhadap peraturan dan pengumpulan data, dan memberikan umpan balik langsung kepada tenaga kesehatan lain.

Kelengkapan dokumentasi setelah diterapkan asuhan keperawatan gawat darurat terintegrasi berbasis aplikasi web sistem pakar menunjukkan selisih mean sebesar 57.24 dengan selisih standar deviasi 12.04 Hasil uji Wilcoxon menunjukkan p value $0.002<$ $\alpha 0.05$ maka terdapat pengaruh yang sangat signifikan pada kelengkapan dokumentasi sebelum dan setelah. Penelitian Finley \& Boie (2006) menyatakan bahwa penyedia layanan kesehatan adalah tanggung jawab berkelanjutan untuk menyediakan dokumentasi. Kelengkapan dokumentasi diperlukan untuk tujuan penagihan, jaminan kualitas, dan manajemen risiko, serta sebagai komunikasi antar tenaga kesehatan. Kelengkapan dokumentasi akan menyediakan pelayanan keperawatan yang berkelanjutan, sehingga perawat mengetahui setiap perkembangan dan kebutuhan klien.

Menurut Kusrini, (2006 : 15) adapun keuntungan dari sistem pakar adalah sebagai berikut membuat seorang yang awam dapat bekerja seperti layaknya seorang pakar; dapat bekerja dengan informasi yang tidak lengkap atau tidak pasti; meningkatkan output dan produktifitas. Sistem pakar dapat bekerja lebih cepat daripada manusia. Keuntungan ini berarti mengurangi jumlah pekerja yang dibutuhkan, dan akhirnya akan mereduksi biaya; meningkatkan kualitas; sistem pakar menyediakan nasehat yang konsisten dan dapat mengurangi tingkat kesalahan; membuat peralatan yang kompleks lebih mudah dioperasikan karena sistem pakar dapat melatih pekerja yang tidak berpengalaman; handal; sistem pakar tidak akan lelah atau bosan; memiliki kemampuan untuk memecahkan masalah 
yang kompleks; memungkinkan pemindahan pengetahuan ke lokasi yang jauh serta memperluas jangkauan seorang pakar, dapat diperoleh dan dipakai di mana saja, sehingga asuhan keperawatan dengan aplikasi web berbasis sistem pakar sangat berperan dalam peningkatan kualitas dokumentasi keperawatan.

\section{KESIMPULAN}

Hasil penelitian menunjukkan bahwa penggunaan asuhan keperawatan gawat darurat terintegrasi berbasis aplikasi web Sistem Pakar efektif dalam meningkatkan ketepatan dan kelengkapan dokumentasi keperawatan. Hasil penelitian ini dapat memberi manfaat bagi pelayanan kesehatan, sehingga mempermudah perawat dalam melakukan dokumentasi sebagai legalitas tindakan dan perlindungan hukum.

\section{SARAN}

Penyediaan sarana dan prasarana yang memadai sesuai dengan kebutuhan klien yang menunjang terkait dengan penegakkan asuhan keperawatan yang diberikan khususnya kelangkapan sarana pendokumentasian keperawatan berbasis web sistem pakar; malakukan penelitian prosedur tetap terkait dengan praktek pelayanan asuhan keperawatan mengacu pada standar praktik keperawatan berdasarkan proses keperawatan dengan memperhatikan konsep patien safety, guna meningkatkan mutu pelayanan; meningkatkan kualitas pelayanan asuhan keperawatan terutama pada kepuasan klien dengan selalu memberikan angket terkait pelayanan keperawatan di IGD.

\section{UCAPAN TERIMAKASIH}

Terima kasih yang sebesar-besarnya kepada:

(1) RISTEKDIKTI yang telah memberikan bantuan dana kepada peneliti untuk melaksanakan penelitian ini;

(2) Maria Adelheid Ensia, S. Pd.. M. Kes selaku Ketua STIKes Eka Harap Palangka Raya yang telah 
memberikan ijin dan dukungan bagi

penulis untuk melakukan penelitian;

(3) LPPM STIKes Eka Harap yang telah memberikan dukungan dan memfasilitasi peneliti dalam melakukan proses penelitian;

(4) Seluruh rekan kerja civitas akademika di STIKes Eka Harap Palangka Raya, atas dukungan dan semangat yang diberikan;

(5) Responden di IGD RSUD RSUD dr. Doris Sylvanus yang telah berpartisifasi dalam penelitian ini.

\section{DAFTAR PUSTAKA}

Nonutu, Prissy Thalia, Mulyadi, \& Malara, Reginus: Hubungan Jumlah Kunjungan Pasien Dengan Ketepatan Palaksanaan Triase Di Instansi Gawat Darurat RSUP Prof. DR. R.D. Kandou, Manado. eJournal Keperawatan (e-Kp). Volume 3, Nomor 2, Mei (2015).

Pertiwi, Satiya Puspa. \& Sugiyanto, Zaenal.: Analisa Kuantitatif Dan Kualitatif Ketidaklengkapan Pengisian Dokumen Rekam Medis Pasien Rawat Inap Pada Penyakit Diare Di RS. Permata Medika Semarang Periode Triwulan I Tahun 2014. Fakultas Kesehatan, Universitas Dian Nuswantoro Semarang. (2014).
Berthiana.: Hubungan Motivasi Kerja Perawat Dengan Ketepatan Pengisian Dokumentasi Asuhan Keperawatan Di Ruang Rawat Inap RSUD Buntok. Jurnal Managemen Keperawatan. Volume 1, Nomor 1, Mei 2013: 57-72. (2012).

Suryagustina, Karmitasari Yanra Katimenta, Dewi Apriliyanti.: The effect of the integrated emergency form and Manual to the accuraly and completeness of Nursing documentation in the hospital Emergency unit, rsud mas amsyar kasongan dan rsud pulang pisau central borneo. Proceedings of the 2nd Sari Mulia International Conference on Health and Sciences 2017 (SMICHS 2017). URL: https://www.atlantispress.com/proce edings/smichs-17/25886855. DOI:10.2991/smichs-17.2017.77 (2017).

Nursalam.: Manajemen Keperawatan. Edisi 3. Jakarta: Salemba Medika. (2011).

Yanti, R.I dan Warsito, B. E.: Hubungan Karakteristik Perawat, Motivasi, Dan Supervisi Dengan Kualitas Dokumentasi Proses Asuhan Keperawatan. Jurnal Managemen Keperawatan. Volume 1, No. 2. Universitas Diponegoro. (2013).

Cheevakasemsook A, Chapman Y, Francis $\mathrm{K}$, Davies C.: The study of nursing documentation complexities. International Journal of Nursing Practice. Vol 12: 366-374. DOI: 10.1111/j.1440-172X.2006.00596.x. Source: PubMed. (2006). 
Wahyudi, Iwan, Dewi Irawaty, dan Sigit Mulyono.: Hubungan Persepsi Perawat tentang Profesi Keperawatan, Kemampuan, dan Motivasi Kerja terhadap Kinerja Perawat Pelaksana di RSUD $d r$. Slamet Garut. Jurnal Keperawatan FIKUI, (2010).

Diyanto, Y.: Analisis FAktor-Faktor Pelaksanaan Dokumentasi Asuhan Keperawatan Di Rumah Sakit Umum Daerah Tugureji Semarang. Tesis, Universitas Dipenogoro Semarang. (2007).

Marton, Anne.: Emergency Nursing. The Journal of Emergency Nursing. (2013).

Siswanto, L. M. H, dkk.: Faktor-Faktor yang Berhubungan dengan Kelengkapan Pendokumentasian Asuhan Keperawatan. Jurnal Keperawatan Indonesia. Vol 16. No. 2. pISSN: 1410-4490. eISSN: 23549203. Depok: Universitas Indonesia. (2013). 